\title{
COLLEGES, CHARITIES, AND THE REVENUE ACT OF 1950
}

\author{
"Eventually all the noodles produced in this country will be \\ produced by corporations held or created by universities...." \\ Representative Dingell of Michigan*
}

Wrry the avowed purpose of preventing tax-exempt institutions from producing all the noodles in this country, Congress in 1950 imposed a tax on the "unrelated business income" of educational, charitable, and other exempt organizations. ${ }^{1}$ Congress' concern was twofold: loss of income to the federal treasury, and unfair competition between taxable and tax-exempt businesses.

The legislators lacked precise information, however, regarding the extent to which exempt organizations are operating commercial enterprises. What information the Treasury had, it would disclose only in executive session; but even the Treasury admitted that its information was spotty, because in the past many exempt organizations have not been required to file informational returns. ${ }^{2}$ Secretary Snyder, in his opening statement to the House committee, stated that "[s]ome colleges and other institutions are engaging in a wide variety of business undertakings, including the production of such items as automobile parts, chinaware, and food products, and the operation of theatres, oil wells, and cotton gins." 3 No doubt one institution which the Secretary had in mind was New York University, whose commercial enterprises include the Mueller Company, a leading manufacturer of macaroni, ${ }^{4}$ the Ramsey Corporation, a manufacturer of piston rings, the American Limoges China Company, and the Howes Leather Company, the latter with assets of 35 milliön. ${ }^{5}$

*Hearings before Committee on Ways and Means on Revenue Revision of 1950, 81st Cong., 2d Sess. 580 (1950) (hereafter cited as House Hearings).

1. Revenue Act of 1950, Pub. L. No. 814, 81st Cong., 1st Sess. (September 23, 1950).

2. "Mr. Bogcs. Does the Treasury Department have any information, any facts or figures, on the number of commercial enterprises operated by colleges and universities?

"Mr. Thonas J. Lxnce [General Counsel, Treasury Department]. We have a list here which we would be glad to provide to the committee. We would prefer to provide it, if we may, in executive session since it is information taken from returns. However, I do want to point out that the information of the Treasury Department is inadequate, because of the fact that the reporting requirements of form 990 , beginning in 1943, excluded a number of organizations under section 101(6). We would not have the information as completely as we would have in respect of the individual income tax, or regular corporation tax." House Hearings 174.

3. House Hearings 19.

4. See the statement of the Tax Court in C. F. Mueller Co., 14 T.C. 922, 925 (1950): "It [C. F. Mueller Co. in the year 1947] was one of the largest operators, and there is some evidence that it was the largest, in the industry."

5. Hearings before Connnittee on Ways and Means on Revente Revisions 1947-48, 80th Cong., 1st Sess. 3529, 3540 (1948) (testimony of John Gerdes, legal counsel, New York University). NYU purchased the Ramsey Corporation in 1945 for a little less than $\$ 3,000,000$. In the two-year period $1946-47$, the corporation made a net profit of $\$ 1,800,000$. Id . at 3531, 3539. American Limoges China, Inc., has assets of approximately 
But apart from a few glaring instances of this sort, facts regarding the commercial activities of exempt organizations are hard to come by ${ }^{6}$ The American Council on Education, in a survey of 1,880 colleges and universities, found that for the fiscal year ending June 30, 1947, 455 of these institutions received a gross income of 150 million from sources other than tuition, appropriations from governmental sources, investment income, and gifts. ${ }^{7}$ The Council failed to obtain complete net income figures, but it estimates that the net income of the 455 institutions would not exceed 12 million, and some of this is from auxiliary services, such as printing plants, dairies, and farms. ${ }^{8}$ The Treasury, however, is somewhat more optimistic, for it predicts that the tax on unrelated business activities will bring in new revenues of about 100 million a year. ${ }^{9}$

$\$ 3,300,000$, and in 1947 it was estimated that its annual net profits would run from $\$ 600,000$ to $\$ 800,000$. At the same time NYU expected the earnings of the Howes Leather Co., Inc., to range from $\$ 2,000,000$ to $\$ 3,000,000$ a year. Id. at 3540 . As to NYU's acquisition of the C. F. Mueller Co., see note 57 infra.

6. Popular writers would have us believe that exempt institutions are running businesses on a large scale. "Tax-exempt companies-enterprises owned by 'trusts' and 'foundations', and religious, charitable, educational, labor and other organizations exempted from federal and some local taxes-are depriving the federal government of hundreds of millions in tax revenues." The Abuse of Tax Exemption, ForTune, May 1950, p. 74. Another writer refers to "the march of the universities down the field of business, banking, real estate, and industry," citing in support of his statement the ownership of a radio station by Gonzaga College, of Willow Run airport by the University of Michigan, of a hydroelectric plant by Utah State College, and of a street railway by Morningside College in Sioux City. Mezerik, The Foundation Racket, New Repuburc, Jan. 30, 1950, pp. 11, 13.

7. House Hearings 572 (testimony of Philip C. Pendleton, treasurer, University of Pennsylvania, and member of committee on taxation, American Council on Education). For a more complete breakdown of the figures, see Communication to the $\mathrm{Y}_{\mathrm{ALE}} \mathrm{L}_{\mathrm{AW}}$ Journal from Francis J. Brown, Staff Associate, American Council on Education, dated Nov. 15, 1950, in Yale Law Library.

8. Ibid.

9. House Hearings 175. Of course the American Council on Education's figure covers only 455 colleges and universities, whereas the Treasury's estimate covers all colleges and universities, as well as all other 101(1), (6), and (7) organizations and certain 101(14) corporations. See page 857 infra. But even so the disparity between total net income of $\$ 12$ million and total taxes of $\$ 100$ million is tremendous. Furthermore, most of the criticism of commercial activity by exempt institutions has been levelled at colleges and universities.

See also the following statement of Mr. Stassen before the Senate Finance Committee: "All of the endowments and resources other than land and buildings of all the private colleges and universities in America are only $\$ 2,000,000,000$. So the gross annual income of all these things, which includes the normal investment in bonds and stocks, and so forth, is obviously something like 5 percent of that, or $\$ 100,000,000$ at a maximum. So you are aiming at a gross of $\$ 100,000,000$ of income, and if 10 percent of it was abusive, you would be aiming at a $\$ 10,000,000$ income, and the tax would be 3 or 4 million dollars." Hearings before Senate Finance Committee on H. R. 8920, 81st Cong., 2d Sess. 514 (1950) (hereafter cited as Senate Hearings). 
A tax-exempt organization can undertake the operation of a commercial enterprise in one of two ways-either directly, i.e., without setting up any separate legal entity, or indirectly through the ownership of a separate "feeder" organization. Different provisions of the new law strike at these two types of ownership.

\section{Direct OWNERSHIP OF Comimercial EnTERPRises}

\section{Developments Prior to 1950}

Prior to 1950, an organization exempt under $\$ 101(6)$ of the Code ${ }^{10}$ did not lose its exemption regardless of how much income it derived from the direct ownership of commercial activities. This policy stems from the Supreme Court's 1924 decision in the Trinidad case. ${ }^{11}$ There, a Philippine religious order obtained approximately $92 \%$ of its income from rents, dividends, and interest. About half of its remaining income was derived from occasional sales of wine, chocolate, and other articles "purchased and supplied for use in its churches, missions, parsonages, schools, and other subordinate agencies."12 In holding that the order was organized and operated exclusively for religious and educational purposes, the Court pointed out that dividends, rents, and interest are a traditional source of income for such institutions and that the receipt of such income does not enlarge the purposes for which the organization is created and conducted. The Court felt that the transactions in wine, chocolate, and other articles did not amount to trade in any proper sense of the term, especially since no sales were made to the general public or in competition with other businesses. It regarded these dealings as "purely incidental" to the pursuit of the exempt purposes, and "in no sense a distinct or external venture."13 Thus the Trinidad case is excellent authority for the proposition that a 101(6) organization may derive income from dividends, rents, and interest without losing its exempt status. But it is negligible

10. INT. REv. CoDE $\$ 101(6)$ exempts from taxation "[c]orporations, and any community chest, fund, or foundation, organized and operated exclusively for religious, charitable, scientific, literary, or educational purposes, or for the prevention of cruelty to children or animals, no part of the net earnings of which inures to the benefit of any private shareholder or individual, and no substantial part of the activities of which is carrying on propaganda, or otherwise attempting, to influence legislation ...." The Commissioner early interpreted the word "private" to modify both "shareholder" and "individual". T.B.R. 33, 1 CuM. Burl. 199 (1919). As used in this section, the term means in a private capacity as distinguished from a public capacity. Earnings do not inure to the benefit of a shareholder or individual "in his private capacity" when they inure to him as one of the public or as a representative of the public. Ibid.

For a general discussion of 101(6), see Tannenbaum, Sale of Business to a Charity, 28 TAXES 723 (1950).

11. 263 U.S. 578 (1924).

12. Id. at 580 .

13. Id. at 581 . 
authority for holding that the 101(6) exemption extends to organizations which operate ordinary commercial enterprises. ${ }^{14}$

Trinidad has not been so interpreted, however. Later courts, seizing on a dictum in that case to the effect that "it [the statute] says nothing about the source of the income, but makes the destination the ultimate test of exemption,"15 have held that a 101(6) organization does not lose its right to exemption regardless of the extent of its business activities. Probably the most extreme example is the Sand Springs Home case, ${ }^{16}$ a 1927 decision of the Board of Tax Appeals, later acquiesced in by the Commissioner. ${ }^{17}$ There, a corporation conducting extensive charitable activities owned and operated a cotton gin, sold oil to refineries and gas to distributing companies, generated and sold electricity, and maintained reservoirs which sold water to the public. These enterprises accounted for substantially all the corporation's income, and many of them were in direct competition with taxable businesses. Yet the Board of Tax Appeals, regarding this situation as "practically identical" with that in the Trinidad case, held the corporation to be exempt. Since then there have been no decisions or rulings denying exemption because a 101(6) organization engages directly in business. ${ }^{18}$

14. For a similar viewpoint, see Latcham, Private Charitable Foundations: Some Tax and Policy Implications, 98 U. of PA. L. REv. 617, 632 (1950).

15. 263 U.S. 581 (1924).

16. 6 B.T.A. 198 (1927). An earlier decision of the Board of Tax Appeals applying the Trinidad rationale was Unity School of Christianity, 4 B.T.A. 61 (1926). In that case most of the corporation's income came from contributions; a small amount from publications, an inn, and a farm. None of these activities was conducted for the purpose of making a profit, however; and a detailed cost accourting system was maintained so that prices could be set at cost. The Board held that the corporation was exempt because its financial activities were merely incidental to its charitable purpose. Thus the Unity situation was considerably closer to the Trinidad case than was the Sand Springs situation.

17. VI-1 Cus. Bull. 5 (1927).

18. See Blodgett, Taxation of Businesses Conducted by Charitable Organizations, New York University Fourte Annual Institute on Federal Taxation 418, 425 (1946). The cases prior to 1946 are collected in id. at 426 n.14. For cases since that date, see Edward Orton, Jr. Ceramic Foundation, 9 T.C. 533 (1947), aff'd, 173 F.2d 483 (6th Cir. 1949) (testamentary foundation organized to advance the ceramic arts, which derived bulk of its income from the manufacture and sale of pyrometric cones, held exempt under 101(6)) ; Community Services, Inc. v. U.S., 50-2 CCH U.S. TAX CasEs. $\{9506$ (E. D. S. C. 1950) (charitable corporation which operated a canteen refreshment service in the plants of a textile company and sold coal, ice, gasoline, oil, and electrical home appliances to employees of the company, all of which had formerly been done by the textile company itself, held exempt from social security taxes under $\$ 1426(b)(8)$ ). See also Blodgett, Charities in Business, NEw YoRK UnIversity EIgHTH ANNUAL INSTITUTE ON FEDERAL TAXATTON 1133, 1136-40 (1950). 


\section{The 1950 Act}

Sections 421-424, added by the new Act, impose a tax on the "unrelated business net income" of all 101(1), (6), and (7) organizations, and certain $101(14)$ organizations. ${ }^{19}$

Unrelated business net income. The computation of unrelated business net income begins with determining the "gross income derived ... from any unrelated trade or business . . regularly carried on."20 Congress expressly excluded from gross income what it regarded as "passive" income: dividends, interest, annuities, royalties, rents from real property (except rents from "Supplement U leases"21), and capital gains. ${ }^{22}$ In support of these extensive exclusions the Ways and Means Committee gave a purely historical reasoni.e., that these types of income "have long been recognized as proper for educational and charitable organizations." ${ }^{23}$ The Senate Finance Committee added a reason of its own: that investments of this sort "are not likely to result in serious competition for taxable businesses having similar income."24

19. Strictly speaking, $\$ 421$ imposes a tax on "Supplement $U$ net income," which is defined as the amount by which "unrelated business net income" exceeds $\$ 1,000$. See text at note 42 infra. Sections $421-424$ are together known as "Supplement U."

20. INT. REv. CODE $\S 422$ (a).

21. This Comment does not treat the subject of rents from "Supplement $U$ leases." Instead, that subject is discussed in Note, page 879 infra, which should be considered together with this Comment.

22. INT. REV. CODE $\$ \S 422(a)(1)-(5)$.

23. H.R. Rep. No. 2319, 81st Cong., 2d Sess. 38 (1950) (hereafter cited as House REPORT). Of course the exclusion of dividends and interest was exceedingly important to all universities with sizable endowments. And the exclusion of rents (other than rents from Supplement $U$ leases) was very much to the interest of some of them. Columbia University, for example, because of its large investment in Rockefeller Center, derives annually about $2 \mathrm{I} / 2$ times as much income from rents as from investments in securities. Columbia University, Report of the Treasurer, June 30, 1944 (1944). In the case of the University of Pennsylvania, rents account for approximately $1 / 6$ as much income as do investments in securities. UnIVERSity of PENNSYlvania, Treasurer's REPORT FOR 1946 (1946). With universities like Harvard and Princeton, on the other hand, rents are a relatively minor source of income. At Harvard rents are less than 120 as important as securities income-wise, and in the case of Princeton this ratio drops to 1/100. Harvard University, Financial Report for 1948-49 (1949); Princeton UNIVERSity, FinANCIAL RePORT FOR THE YeAR ENDING JUNE, 1941 (1941).

24. Sen. Rep. No. 2375, 81st Cong., 2d Sess. 30-1 (1950) (hereafter cited as SENATE REPoRT). For a contrary view, see the testimony of John Gerdes, legal counsel, New York University, in the 1947 hearings before the Ways and Means Committee. "I do not know of any moral or legal difference between income received by a taxexempt organization in the form of profits from the operation of a business and any of the following forms of income: Interest or dividends on securities; rents or profits from the operation of real estate; or profits from the purchase and sale of securities and real or personal property. As to each kind of income, there is competition with private enterprise." Hearings, supra note 5, at 3530 . Aside from the brief statement of the Senate Finance Committee, supra, the 1950 Congress never came to grips with this question of why one type of activity on the part of an exempt institution is more competitive with private enterprise than another. 
Congress excluded income derived from research for the United States or for any state, because it felt that such work usually is not undertaken on a profit-making basis. ${ }^{25}$ It also excluded, in the case of a college, university, or hospital, and in the case of an organization "operated primarily for the purposes of carrying on fundamental research the results of which are freely available to the general public," income derived from research performed for any person. ${ }^{26}$

Congress intended that the term "trade or business," as used in $\S 422$, should have the same meaning that it has in other sections of the Code, such as 23 (a) (1). ${ }^{27}$ The tax, however, is imposed only on income from an "unrelated" trade or business, which $\S 422$ (b) defines as "any trade or business the conduct of which is not substantially related (aside from the need of such organization for income or funds or the use it makes of the profits derived) to the exercise or performance by such organization" of its exempt purpose. The committee reports give various examples of "related" businesses: athletic activities of schools; university dining halls and dormitories; a university press; a wheat farm operated by an agricultural college as part of its educational program; the sale by an organization engaged in the rehabilitation of handicapped persons of articles made by such persons; and the treatment of "paying" patients by a non-profit hospital which also treats charity patients. ${ }^{28}$ In addition, 422(b) contains three specific exclusions from the "unrelated" category: a business in which substantially all the work is performed for the organization without compensation $;^{29}$ a business carried on by a 101(6) organization primarily for the convenience of its members, students, patients, officers, or employees, such as a laundry operated by a college for the purpose of laundering students' clothing; and a business which consists of selling merchandise, substantially all of which has been contributed to the organization, as in the case of a "thrift shop."

A trade or business must not only be "unrelated" before its profits will be taxed-it must also be "regularly carried on." This same phrase appears in $\S 122$ (d) (5), but there the shoe is on the other foot, because the taxpayer is trying to show that a trade or business $i$ carried on regularly. The committee reports point out that a charitable organization which gives an occasional public dance, or an organization which operates a sandwich stand during the week of an annual county fair, does not carry on a regular business.

25. INT. REv. CODE $\$ 422$ (a) (7); House REPORT 37 ("most of this work is done on a cost basis") ; Senate Report 30 ("Work done for State and local governments, as well as work done for the Federal Government, is excluded since it is not believed that such work is ordinarily undertaken on a profit-making basis.").

26. INT. REv. CODE $\S 422(a)(8)$.

27. HOUSE REPORT 109.

28. Id. at 37, 109-10; Senate Report 29, 107.

29. The Ways and Means Committee gave as an example of this exclusion a second-hand clothing store run by an exempt orphanage, with substantially all the work performed by volunteers without compensation. HOUSE REPORT 110. 
But the operation of a public parking lot one day each week, or the operation of a race track a few weeks each year, is to be regarded as carrying on a business regularly. ${ }^{30}$

Once an organization has determined its gross income from an unrelated trade or business regularly carried on, it can subtract, with certain exceptions, the deductions allowed by $\S 23$ which are "directly connected with" the carrying on of the trade or business. ${ }^{31}$ This may give rise to tough problems of allocation. If a university generating plant supplies electricity to a commercial laundry owned by the university, it may be difficult to allocate this item of overhead. Apart from the general requirement that deductions be "connected" with the unrelated business, certain deductions are expressly excludednamely, all those "directly connected with" the types of income excluded from gross income. ${ }^{32}$ For example, capital losses and all deductions directly connected with dividends and interest are excluded.

The net operating loss deduction is allowed, except that it is to be determined without taking into account any income or deductions excluded in determining unrelated business net income. ${ }^{33}$ Thus a loss attributable to an unrelated trade or business will not be diminished for purposes of determining the net operating loss carry-back or carry-over by reason of the receipt of substantial dividend income. The charitable contribution deduction provided for by $\S \S 23(\mathrm{o})$ and $23(\mathrm{q})$ is allowed, but is limited to $5 \%$ or $15 \%$ (depending upon whether the organization is taxable at corporate or individual rates) of the unrelated business net income computed without benefit of the charitable contribution deduction itself. ${ }^{34}$ The contribution, moreover, is allowable only if it is paid to another organization. ${ }^{35}$

Organizations subject to tax. Generally speaking, the tax on unrelated business net income hits all 101(1), (6), and (7) organizations, and those 101(14) corporations whose income is payable to a $101(1),(6)$, or (7) organization. ${ }^{30}$ Apparently the Treasury's original intention was to include $101(8)$ and (9) organizations as well, but this intention was abandoned before the bill was reported out of the Ways and Means Committee. ${ }^{37}$

30. Id. at 109; SenATE Report 106-7.

31. INT. REv. CODE § 422 (a).

32. Id. $\S 422$ (a) (1), (2), (3), (5), (7), and (8).

33. $I d$. $\$ 422(\mathrm{a})(6)$.

34. Id. $\S 422(\mathrm{a})(9)$.

35. HOUSE REPORT 111.

36. INT. Rev. CODE $\S 421(b)$. Section 101(1) exempts from taxation "[1]abor, agricultural, or horticultural organizations"; $\$ 101(7)$ exempts "[b]usiness leagues, chambers of commerce, real-estate boards, or boards of trade, not organized for profit and no part of the net earnings of which inures to the benefit of any private shareholder or individual"; $\$ 101(14)$ exempts "[c]orporations organized for the exclusive purpose of holding title to property, collecting income therefrom, and turning orer the entire amount thereof, less expenses, to an organization which itself is exempt from the tax imposed by this chapter."

37. See the statement of Vance Kirby, Tax Legislative Counsel, Treasury Department: 
It is surprising that 101(1) and (7) organizations were included in the Act. Interpretation of these subsections by the Commissioner and the courts has not paralleled their broad interpretation of $101(6)$. As the Treasury itself pointed out in the hearings, exempt labor and agricultural organizations and business leagues can engage in activities ordinarily carried on for profit only if the activities are incidental or subordinate to the principal purpose for which exemption is granted. ${ }^{38}$ As a result of this limitation, such organizations carry on business-type activities on a comparatively small scale. ${ }^{39}$

"Mr. MIILs. How many of these paragraphs, these 19 paragraphs under 101, would we amend if we carried into existence the suggestions you make in this memorandum? Would we just amend 101-6?

"Mr. KrRBy. No. It would apply to some of the other paragraphs. . .

"Mr. Mrrls. . . . I am trying to think of the 19 situations enumerated in section 101. How many of those situations would be affected by this?

"Mr. KrRBy. There are five. For example, the business leagues, labor unions, social clubs [\$101(8)] and civil leagues [\$101(9)] in addition to the charitable and education organizations." House Hearings 169.

38. E.g., Uniform Printing \& Supply Co. v. Commissioner, 33 F.2d 445 (7th Cir. 1929), cert. denied, 280 U.S. 591 (1929) (corporation organized by various fire insurance companies to print uniform forms and policies, held not exempt as a business league because organized for profit); Underwriters Laboratories, Inc. v. Commissioner, 135 F.2d 371 (7th Cir. 1943) (corporation organized by fire insurance companies to carry on research work as to insurance hazardis and risks, held not exempt as a business league because organized for profit) ; A.R.M. 79, 1 CuM. BULL. 235 (1920) (association organized to publish a breed register for profit, held not exempt as an agricultural association). In addition to the express words of $\$ 101(7)$, which requires that a business league be "not organized for profit," U.S. Treas. Reg. 111, \$29.101(7)-1 (1943) provides that "[a]n organization whose purpose is to engage in a regular business of a kind ordinarily carried on for profit, even though the business is conducted on a cooperative basis or produces only sufficient income to be self-sustaining, is not a business league."

For the Treasury's statement regarding 101(1) and (7) organizations, see House Hearings 114.

In a similar manner, the Commissioner and the courts have construed strictly the language of $\$ 101(14)$ - "corporations organized for the exclusive purpose of holding title to property [and] collecting income therefrom." They have denied exemption under that subsection to corporations which engage in ordinary commercial activities. Gagne v. Hanover Water Works Co., 92 F.2d 659 (1st Cir. 1937) (water company all of whose stock was held by Dartmouth College and village precinct of Hanover); I.T. 2906, XIV-2 CuM. BuLs. 116 (1935) (tea room all of whose stock was held by an exempt association); O.D. 60, 1 Cux. Burc. 193 (1919) (railroad company all of whose income was turned over to a charitable institution). But see N. P. E. F. Corp., P-H 1946 TC MEMr. DEc. $\int 46,100$ (1946), in which a corporation organized by trustees of an exempt fraternity was held exempt under 101(14), despite the fact that it not only managed a $\$ 100,000$ fund but also conducted an extensive lending program. During the taxable year the corporation had made loans of $\$ 2,200$ to ten student members of the fraternity and loans of $\$ 22,000$ to various chapters for the purpose of buying or building fraternity houses.

39. House Hearings 114. 
Churches as such are exempt from the tax on unrelated business income. This exemption does not extend to other religious organizations, however, nor to educational and charitable organizations founded under church auspices. Furthermore, a 101(14) corporation all of whose income is payable to a church is not exempt.40

Computation of tax. Unrelated business income is to be taxed at corporate rates for corporations and at individual rates for trusts. ${ }^{41}$ Thus if a person is setting up a 101(6) organization which will have substantial unrelated business income, it will be better tax-wise to use a corporation than a trust. All organizations are given a basic exemption of $\$ 1,000.42$ This, along with the requirement that a business must be "regularly carried on," was designed by Congress to eliminate the nuisance cases. ${ }^{43}$ Section $101(1),(6)$, and (7) organizations may find it advantageous to split up their Supplement U leases among a number of 101 (14) corporations, in order to use the $\$ 1,000$ exemption to the hilt, and in order to avoid the surtax.

$\$ 162$ trusts. Section $162(\mathrm{~g})(1)$, the counterpart of Supplement U for $\$ 162$ trusts, may present a special problem. A trust which can bring itself within the terms of $101(6)$ has the option of claiming exemption under that section or deducting its entire income under $162(\mathrm{a}) .^{44} \mathrm{~A}$ trust which is in part charitable and in part non-charitable, on the other hand, must look exclusively to $162(\mathrm{a})$ if it is to avoid tax on that part of its income devoted to charitable purposes. Section 162 (a) permits a trust, in lieu of the $15 \%$ charitable contribution deduction of $\S 23(0)$, an unlimited deduction for any part of its gross income which, pursuant to the terms of the will or deed creating the trust, is "paid or permanently set aside for purposes and in the manner specified in section $23(0)$," or "is to be used exclusively" for an exempt purpose. ${ }^{45}$

40. INT. REv. CODE $\$ 421$ (b) (1) ; House REPORT 108. The exemption of churches extends also to "an association or convention of churches." This was added by the Senate Finance Committee to accommodate the Baptist church. See Senate Hearings 216 (statement of A. B. Culbertson on behalf of Southern Baptist Convention); SENate REPORT 106.

41. INT. REv. CODE §421(a).

42. Id. $\S 421$ (c).

43. Senate Report 30.

44. The Commissioner originally ruled that a private charitable trust could never be exempt under 101(6) on the theory that the term "community", as used in that subsection, modified the three words "chest", "fund", and "foundation". Therefore a trust, to be exempt, had to be created and supported by community contributions. S.M. 2620, III-2 CuMr. BuLl. 221 (1924). But after the Sixth Circuit had held otherwise in 53rd Union Trust Co. v. Commissioner, 56 F.2d 767 (6th Cir. 1932), the Commissioner accepted this decision and rescinded his prior ruling. G. C. M. 15778, XIV-2 Cuar. Bull. 118 (1935).

45. Section $162(\mathrm{a})$ is broader in scope than $\S 23(\mathrm{o})$. By allowing a deduction for income which is "to be used exclusively" for charitable purposes, it permits direct disbursements to charity. Section $23(0)$, on the other hand, requires that income be paid 
Section $162(\mathrm{~g})(1)$, added by the new Act, provides that no amount otherwise allowable under 162 (a) as a deduction shall be allowed with respect to income "which is allocable to" the trust's Supplement $U$ business income. Supplement $U$ business income is in turn defined as an amount equal to what the trust's unrelated business net income would be under 422 if the trust were exempt under 101(6). But Congress nowhere said how the Commissioner is to determine what income of the trust is "allocable to" its Supplement $U$ business income. For example, a trust $50 \%$ of whose income is payable to private and $50 \%$ to charitable beneficiaries, might derive $10 \%$ of its total income from commercial enterprises or from Supplement U leases. Will the Commissioner presume that all this Supplement U business income goes to the charitable beneficiaries, that it all goes to the private beneficiaries, or that half goes to each? ? $^{46}$

over to an organization organized and operated exclusively for an exempt purpose. Thus a trust can deduct payments made directly to needy widows and' orphans, whereas an individual can not.

46. The House Report sets forth one hypothetical case which indicates that in the situation stated above the Commissioner should treat half of the Supplement $U$ income as going to the charitable beneficiaries. HOUSE REPORT 127-8. In other words, the Commissioner should disallow as a deduction under 162(a) the same percentage of the amount paid or set aside for exempt purposes as the Supplement $U$ business income is of the total income of the trust.

Under some circumstances a trust which operates a commercial enterprise may be classified as a corporation for tax purposes. INT. REv. ConE $\$ 3797$ (a) (3) defines the term "corporation" to include "associations". In Morrissey v. Commissioner, 296 U.S. 344 (1935), the Supreme Court laid down three basic tests for determining whether any unincorporated organization should be classified as an "association": (1) associates in a joint enterprise; (2) business purpose; and (3) substantial resemblance to a corporation. The Court also specified five subsidiary tests for determining whether a particular enterprise complies with the third basic test of substantial resemblance to a corporation: (a) title vested in a single entity; (b) centralized management; (c) continuity; (d) transferability of beneficial interests; and (e) limitation of personal liability. For an analysis of how these tests have fared in subsequent decisions, see Smith, Associations Classificd as Corporations Under the Internal Revenue Code, 34 CALIF. L. Rev. 461 (1946) ; Latcham, Private Charitable Foundations: Some Tax and Policy Implications, 98 U. of PA. L. Rev. 617, 635-7 (1950).

As Smith interprets the Morrissey dicta, "associate" includes only persons beneficially interested, and there must be more than one beneficially interested person before an organization can be classified as an association. Thus one beneficiary and several trustees cannot be "associates" within the meaning of the Morrissey case. Smith, supra, at 471. But Lombard Trustees v. Commissioner, 136 F.2d 22 (9th Cir. 1943), holding a trust taxable as a corporation even though it had only one beneficiary during part of the taxable year, casts doubt on this theory. See Latcham, supra, at 636.

Smith concludes that of the five subsidiary tests suggested in Morrissey to determine whether an organization has a "business purpose", only a substantial degree of continuity, centralized management, and transferability are essential, and that the remaining twotitle vested in a single entity and limitation of personal liability-are irrelevant. "Virtually all the decided cases fit into this pattern." Smith, supra, at 534. 
Conclusion. These fairly elaborate provisions for taxing unrelated business income are relatively insignificant, however. Those commercial enterprises which are owned by exempt institutions are seldom owned directly. One reason may be that the charters of some colleges forbid such excursions. ${ }^{47}$ But no doubt the main reason is that exempt institutions do not want to expose their funds to the hazards of business. ${ }^{48}$ Therefore most commercial enterprises are operated through a "feeder" organization-an organization which does not itself dispense charity or education, but rather produces income for an organization which does. ${ }^{49}$

\section{"Feeder" Organizations}

\section{Developments Prior to 1950}

Before the new Act, educational and charitable institutions which operated commercial enterprises through separate feeder organizations rather than directly were only slightly less favored by the Commissioner and the courts. When the parent organization received from the subsidiary dividends or trust income (depending upon whether the subsidiary was organized as a corporation or a trust), that income was not taxed to the parent. Furthermore, the subsidiary organization paid no corporate or individual income tax, because it was itself held to be exempt under $\$ 101(6)$.

The leading case holding that an organization which "feeds" a 101(6) organization is itself exempt under 101(6), is Roche's Beach v. Commissioner. ${ }^{50}$ Four months before his death the owner of a bathing beach business had transferred all the real estate and equipment of the business to a corporation organized under the New York stock corporation law. He held all the stock and received all the income until his death, whereupon he bequeathed all the stock to testamentary trustees to establish a foundation for the relief of destitute women and children. The corporation's income was

47. See House Hearings 502 (testimony of J. R. Killian, Jr., president, MIT); Senate Hearings 503, 510 (testimony of Harold Stassen, president, University of Pennsylvania). See also Learned Hand, dissenting, in Roche's Beach v. Commissioner, 96 F.2d 776, 779 (2d Cir. 1938).

48. See Assoctation of American Universities, Report of the Consamttee on Financlal Support and Taxation 3 (1950) ("Few boards of trustees of a university would be willing to accept the liability which would be involved in such business enterprises were they to be owned directly by the university, rather than by a separate corporation or foundation."); Senate Hearings 567 (testimony of Stuart Hedden, trustee, Wesleyan College) ("No college board of trustees will subject the endowment directly to the risks of a non-related business without the insulation of an intervening corporation.").

49. See Senate Hearings 375 (testimony of J. R. Killian, Jr., president, MIT, on behalf of Committee on Financial Support and Taxation of the Association of American Universities) ("I know of no business enterprise that is completely owned and operated by a university directly. There may be some but our committee is not aware of it. Every major one that we know of has been set up and handled as a separate entity.").

50. 96 F.2d 776 (2d Cir. 1938). 
derived from rentals of bathhouses, bathing suits, and towels; from concessions given out for restaurants and refreshments; and from the rental of portions of the beach. During the taxable year the corporation had turned over its entire net income of $\$ 23,000$ to the foundation organized by the trustees. The Commissioner, while conceding that the foundation was exempt under 101(6), denied exemption to the corporation under either 101(6) or 101(14) on the ground that the purposes for which a corporation is organized are determined solely by its charter. Here the corporation's charter gave it wide powers for carrying on a variety of businesses and said nothing about the charitable purpose which it was to serve.

The Second Circuit Court of Appeals held that the corporation could not bring itself within 101(14), because the operation of a bathing beach business was broader than merely holding title to property and collecting income therefrom..$^{51}$ But the court, citing the "destination rather than source" dictum in the Trinidad case, held that the corporation was exempt under 101(6). Rejecting the Commissioner's view that the charter was controlling, the court pointed out that the testator's will made it clear that the corporation's income could not be used for other than charitable purposes without a perversion of the testamentary trust. ${ }^{52}$

Roche's Beach has had a somewhat chequered, but on the whole triumphant, career. A few years later the Ninth Circuit Court of Appeals reached the opposite result in a brief opinion which did not even discuss Roche's Beach. ${ }^{53}$ But by and large the Second Circuit's opinion has carried the day. ${ }^{54}$ The Commissioner himself accepted it until 1942,55 and even after he decided

51. For similar interpretations of $\$ 101(14)$, see note 38 supra.

52. Learned Hand dissented on the ground that since Congress in $\$ 101(14)$ specifically exempted certain feeder corporations, it intended to exempt no others. 96 F.2d 776, 780.

53. Bear Gulch Water Co. v. Commissioner, 116 F.2d 975 (9th Cir. 1941) (water company all of whose stock was owned by the Regents of University of California, held not exempt under 101(6).

54. In Home Oil Mill v. Willingham, 68 F. Supp. 525 (N.D. Ala. 1945), 86 F. Supp. 568 (N.D. Ala. 1949), aff'd, 181 F.2d 9 (5th Cir. 1950), the court, citing Roche's Beach, held a feeder corporation to be exempt under $101(6)$ even though it was originally organized and operated as a non-charitable corporation. The court of appeals regarded an amendment of the corporation's charter providing that it would henceforth be operated exclusively for charitable purposes as a "legal rebirth." For a contrary view, see Universal Oil Products Co. v. Campbell, 181 F.2d 451 (7th Cir. 1950) (corporation held not exempt under 101(6), despite a charter amendment requiring that it be operated exclusively for exempt purposes, on ground that it had not been "organized" for such purposes).

In Debbs Memorial Radio Fund, Inc., v. Commissioner, 148 F.2d 948 (2d Cir. 1945) (corporation which operated a radio station held to be exempt under 101(8) as a civic organization "operated exclusively for the promotion of social welfare"), the Second Circuit stated: "[W]e shall continue to [adhere to the Roche's Beach decision] until instructed otherwise by final authority."

55. The Commissioner had accepted the basic principle of Roche's Beach-that a corporation organized and operated to "feed" a charitable organization is itself exempt 
that it should no longer be controlling the Tax Court did not follow suit.6 Not until the C. F. Mueller case in May, 1950, did the Tax Court join the Commissioner in rejecting Roche's Beach. ${ }^{\mathbf{5 7}}$

under 101(6) -as early as I.T. 1945, III-1 CuM. BuLL. 273 (1924). His contention in Roche's Beach was simply that the charter is determinative of the purposes for which a corporation is organized. After that decision he modified his previous ruling to provide that a corporation's exemption would not be defeated if "some other binding instrument" required that its net income be used exclusively for charitable purposes. G.C.M. 21610, 1939-2 Cum. Bull. 103. And in G.C.M. 20853, 1938-2 Cum. Butx. 166, he relied squarely on Roche's Beach in holding that an association which operated a cemetery for the benefit of several religious organizations was itself exempt under $101(6)$. But a few years later he apparently rejected both aspects of the Roche's Beach decision. G.C.M. 23063, 1942-1 Cun Bull. 103 ("This office ... is now of the opinion that the decision ... should no longer be followed.").

For cases holding an organization to be exempt under $101(6)$ even though there was no binding instrument requiring that its net income be used exclusively for charitable purposes, see Commissioner v. Battle Creek, Inc., 126 F.2d 405 (5th Cir. 1942); Unity School of Christianity, 4 B.T.A. 61 (1926) ; N. P. E. F. Corp., P-H 1946 TC MEM. DEC. If 46,100 (1946) (exemption under 101(14)).

56. Estate of Louise V. Simpson, 2 T.C. 963 (1943).

57. 14 T.C. 922 (1950). Henry Mueller, the president of C. F. Mueller Company and owner of $60 \%$ of its outstanding stock, died in 1946. His estate needed funds to pay income and inheritance taxes. A group of persons interested in the NYU law school organized the new Mueller company, which in turn purchased from Mueller's estate and from the other stockholders all the outstanding stock of the old company for an aggregate price of $\$ 3,495,000$. The new company financed the purchase by borrowing $\$ 3,550,000$ from the Prudential Insurance Company. The loan agreement required that $75 \%$ of the corporation's income be used to reduce the loan to $\$ 1,500,000$, and that thereafter the distributions to NYU could not exceed $25 \%$ of net income until the loan was paid. The loan was to be completely repaid within 15 years.

The new company then merged with the old company and cancelled all the old company's stock. The charter of the new company provided that it was organized exclusively for exempt purposes and that no part of its income could inure to the benefit of anyone other than the NYU law school. The company's total authorized stock, consisting of ten shares, was to be held for ten years by voting trustees, after which it was to be transferred to NYU.

The net income of the old company for 1946 was $\$ 962,000$, on which it paid federal income taxes of $\$ 365,000$. The net income of the new company for the four months' period from August 28 to December 31,1947 , was $\$ 359,000$. The new company distributed $\$ 75,000$ to the law school at the end of 1948 and another $\$ 100,000$ at the end of 1949. Ibid.; Hearings, supra note 5 , at 3537.

In holding that the new company was not entitled to exemption under $101(6)$, the Tax Court stated: “The Commissioner's effort to distinguish the Roche's Beach case from the present one is not convincing, and if the two are not distinguishable, then with all due respect, the Tax Court, not being convinced by the reasoning of the majority in the Roche's Beach case, declines to follow it at this time." 14 T.C. 922, 928 (1950).

The Tax Court's decision in the Mueller case was recently reversed by the Third Circuit Court of Appeals. C. F. Mueller Co. v. Commissioner, 19 U.S.L. WEeK 2613 (3d 'Cir. June 26, 1951). 


\section{The 1950 Act}

The new Act overrules Roche's Beach by a brief amendment to $\S 101$. The penultimate paragraph of that section now provides that "[a]n organization operated for the primary purpose of carrying on a trade or business for profit shall not be exempt under any paragraph of this section on the ground that all of its profits are payable to one or more organizations exempt under this section from taxation."

Probably one of the most troublesome questions to arise under this provision will be whether the test set up here-namely, whether an organization is organized for the primary purpose of carrying on a trade or business for profit-differs from the test set up in $\S 422$ (b)-namely, whether the conduct of a trade or business is not substantially related to the exercise of an organization's charitable, educational, or other exempt function. For example, a laundry operated directly by a university primarily for the convenience of students is expressly excluded by $422(\mathrm{~b})$ from the term "unrelated trade or business" even though the laundry makes a profit. A "thrift shop" operated directly by an exempt organization is similarly excluded. But if a separate feeder organization is set up to operate the laundry or the thrift shop, does the income then become taxable? In short, are the exclusions from the "unrelated trade or business" category, both express and implied, to be read into the penultimate paragraph of 101 ? If not, then in some situations it will be more profitable tax-wise to operate a business directly than through a feeder organization.

Even in the case of a business which is certain to be caught either by 422 or by the amendment to 101 , such as a macaroni factory, it may make a difference tax-wise whether it is operated directly or through a separate feeder organization. If it is a feeder, it will be denied exemption under 101 and then taxed at corporate or individual rates depending upon whether it is organized as a corporation or a trust, regardless of its parent's form of organization. If the business is operated directly, however, then the parent's form of organization will control. Thus, quite apart from the advantage of obtaining limited liability, it may now behoove a trust exempt under 101( 6 ) to operate a commercial enterprise through a feeder corporation in order to obtain corporate rather than individual tax rates. On the other hand, if the parent organization is itself a corporation, then it may be better taxwise to run the macaroni factory directly than through a feeder. A feeder corporation, for example, will be taxed on capital gains and on $15 \%$ of intercorporate dividends received. If the macaroni factory is owned directly and its income taxed to the parent as "unrelated business income" under 422 , however, both these items of income will be excluded. Similarly, in the latter case the receipt of dividend income will not offset a loss from the operation of the business for purposes of computing the net operating loss deduction. .s

58. See page 857 supra. 
The amendment to $\S 101$ applies to all feeder organizations, not just those all of whose income is payable to a $101(1),(6)$, or (7) organization. No exception is made for churches, as in the case of the tax on unrelated business income. The only express exclusion from "trade or business" which the amendment makes is the rental by an organization of its real property (including personal property leased with the real property). ${ }^{50}$

\section{Promibited Transactions}

In addition to taxing, in whole or in part, organizations heretofore exempt, Congress wanted to discourage certain dealings between donors and trusts or foundations created by them. To that end it set forth a list of "prohibited transactions." 60 If certain 101(6) organizations, mainly private charitable trusts, ${ }^{61}$ engage in a prohibited transaction, they lose their exemp-

59. Both the Ways and Means Committee and the Senate Finance Committee stated that the amendment to $\S 101$ was intended to have no effect on corporations exempt under 101(14). House Report 41; Senate Report 35. But the amendment's exclusion of "the rental by an organization of its real property (including personal property leased with the real property)" is not coextensive with 101(14), which also exempts corporations holding title to personal property, such as securities, and collecting the income therefrom. The Commissioner might seek to take advantage of this discrepancy by holding that a corporation which simply holds securities, collects dividends and interest, and then distributes the proceeds to other exempt organizations, is "operated for the primary purpose of carrying on a trade or business for profit" and hence is no longer entitled to exemption under either 101(6) or (14). But, quite apart from the language in the committee reports, supra, it is very doubtful whether Congress, in amending $\$ 101$, intended to deny exemption to feeder organizations which merely manage investments. Furthermore, if the organization involved were a trust it could deduct its entire income under 162(a), even if it were denied exemption under $101(6)$.

60. INT. REV. CoDE $\$ \$ 3813(b), 162(\mathrm{~g})(2)(B)$.

61. Section 3813 applies to approximately the same 101(6) organizations that are required to file informational returns under §54(f). INT. Rev. CoDE §3813(a). The Senate Finance Committee stated: "The organizations excluded from the application of these provisions are in general what might be called 'public' organizations and because of this characteristic are not likely to become involved in any of these prohibited transactions." Senate Report 38.

There are certain discrepancies between $\S 54(f)$ and $\S 3813$, however. For example, $\$ 54(f)(3)$ excludes an exempt charitable organization which is "primarily supported by contributions of the general public." U.S. Treas. Reg. 111, $\$ 29.101-2(\mathrm{~h})$ (1944) interprets this requirement to mean that at least $50 \%$ of the organization's income must be derived from public contributions. Section 3813(a) (3), on the other hand, excludes an exempt, charity which "normally receives a substantial part of its support" (apart from income received in the performance of its exempt purpose) from "direct or indirect contributions from the general public." (Italics added.) This change was made by the Senate Finance Committee in order to exclude organizations which receive a sizeable part (but less than half) of their income from community chests. See Senate Hearings 542-7 (testimony of Robert Cutler, former national president, Community Chests and Councils of America); Senate Report 123. But no corresponding change was made in $\$ 54(f)(3)$.

Another difference between $\$ \$ 4(f)$ and 3813 is that the latter does not apply to an organization "the principal purposes or functions of which are the providing of medical or 
tion under that subsection. ${ }^{62}$ Similarly, if a $\$ 162$ trust engages in a prohibited transaction, the amount otherwise allowable under $162(\mathrm{a})$ is limited to $15 \%$ of the net income of the trust. ${ }^{63}$

\section{The Transactions Prohibited}

Section 3813 defines six transactions which are "prohibited" if entered into with prescribed persons: (1) lending any part of the organization's income or corpus, without the receipt of adequate security and a reasonable rate of interest; (2) paying any compensation, in excess of a reasonable allowance for salaries or other compensation for personal services actually rendered; (3) making any part of the organization's services available on a preferential basis; (4) making any substantial purchase of securities or other property, for more than an adequate consideration in money or money's worth; (5) selling any substantial part of the organization's securities or other property, for less than an adequate consideration in money or money's worth; and (6) engaging in any other transaction which results in a substantial diversion of income or corpus.

Some of these provisions represent a substantial watering down of the bill as passed by the House. The House bill would have prohibited all loans to, all substantial purchases from, and all sales to, the prescribed persons. ${ }^{64}$ The Senate, rejecting the House provisions as "unduly harsh," could see no objection to transactions between donors and their private charitable trusts provided those transactions were "carried out at arm's length."65 Therefore it introduced several of the phrases which are likely to prove knottiest in the interpretation of the new section: "adequate security," reasonable rate of interest," and "adequate consideration."66

The enumeration of prohibited transactions in $162(\mathrm{~g})(2)$ presents a special problem. A transaction is prohibited only if a trust "holding income or corpus which has been permanently set aside or is to be used exclusively for charitable or other purposes described in subsection (a)," uses "such income or corpus" to make loans or purchases or to pay compensation, or sells or diverts "such income or corpus." But how is "such income or corpus"

hospital care or medical research." Thus such an organization may be required to file an informational return under $54(f)$ even though it is not subject to the prohibited transactions and accumulated income provisions. The Senate Finance Committee, which added this exception to 3813 , gave no explanation why such an organization should not also be relieved of the necessity of filing an information return.

62. INT. REv. CODE $\$ 3813$ (c) (1).

63. Id. $\S 162(\mathrm{~g})(2)(\mathrm{A})$.

64. House Bill $\S 426(\mathrm{c})$, reprinted in 31 P-H Federal Tax Report Bulletin, No. 26 , part 2, p. 29 (June 29,1950 ).

65. Senate Report 37.

66. The phrase "adequate and full consideration in money or money's worth" appears in INT. Rev. Code $\$ \S 811$ (c), (d), (e), (f), (i), 812(b), and 1002. See 1 Paut, FederaI EsTATE AND GIFT TAXATION $\S 8.04,8.06,11.20-11.24$ (1942) ; 2 id. \$§ 16.14-16.15. 
to be identified? For example, in the case of a trust $50 \%$ of whose income is to be devoted to charity and $50 \%$ paid to or accumulated for private beneficiaries, how is the Commissioner to know which part of the income was used to enter into a prohibited transaction? Are the trustee's bookkeeping entries to be determinative? Probably not. ${ }^{67}$ The Commissioner might conclusively presume that if any income or corpus has been permanently set aside or is to be used exclusively for an exempt purpose, that income or corpus was the first to be used in entering into a prohibited transaction. But he would be doing so without support from the hearings or committee reports, for there is no indication that Comgress thought of this problem.

\section{Prescribed Persons}

Any transaction of the sort described above is "prohibited" if entered into with certain persons : the creator of the organization, if a trust; a person who has made a substantial contribution to the organization; a member of the family, as defined in $\$ 24$ (b) (2) (D), of any such creator or contributor; or a corporation controlled by such creator or contributor through the ownership, directly or indirectly, of $50 \%$ or more of the total combined voting power of all classes of stock entitled to vote or $50 \%$ or more of the total value of all classes of stock. ${ }^{68}$

The phrase "ownership, directly or indirectly," may become critical in the interpretation of the prohibited transactions provisions. For example, is a person who creates a charitable trust and transfers stock to it the indirect owner of the stock merely because he is the settlor of the trust? If not, is he more likely to be regarded as the owner of the stock if he designates himself as trustee?68 It is significant that Congress did not provide expressly in $\$ \S 3813$ and $162(\mathrm{~g})(2)$, as it has in several other sections of the Code, that stock owned "by or for a corporation, partnership, estate, or trust, shall be considered as being owned proportionately by or for its shareholders, partners, or beneficiaries."70 In the absence of such a provision, how much

67. Cf. Bowers v. Slocum, 20 F.2d 350 (2d Cir. 1927) (trustee's failure to make bookkeeping entries held immaterial for purposes of deduction under 162(a), where decedent's will required that income be set aside for charitable purposes); E. Sohier Welch v. Commissioner, 9 B.T.A. 1370 (1928) (same).

68. INT. REv. CoDE $\S \S 3813(\mathrm{~b}), 162(\mathrm{~g})(2)(\mathrm{B})$. The House bill also included in the list of prescribed persons "any officer, director, or trustee" of the organization. House bill $\$ \$ 301(c), 331(a)$, stpra note 64 , at 30,32. The Senate Finance Committee gave no reason for eliminating this provision.

69. It should be noted that the Clifford regulations do not deter the settlor of a charitable trust from designating himself as trustee. U.S. Treas. Reg. 111, $\$ 29.22(a)-$ 21(d) (1947), prescribing the circumstances under which trust income is taxable to the grantor because he has the power to dispose of the beneficial enjoyment of the corpus or income, specifically exempts a situation in which the corpus or income "is irrevocably payable for the purposes and in the manner specified in section $23(0)$."

70. This phrase is found in INT. REv. CoDE $\$ \S 24$ (b) (2) (A), 130A(d) (1) (C) (ii), and $503(a)(1)$. 
will the Commissioner and the courts read into the term "indirect ownership" for purposes of 3813 and $162(\mathrm{~g})(2)$ ? A similar phrase appears elsewhere in the Code, particularly in $\$ 24(\mathrm{~b})$ and the personal holding company provisions, ${ }^{71}$ but the broad definition of "constructive ownership" in those sections has apparently obviated most of the questions which might otherwise have arisen under the concept of "indirect ownership."72 For administrative interpretation of this term, it is necessary to look to $\$ 16(a)$ of the Securities Exchange $\mathrm{Act}^{73}$ and $\S 17$ (a) of the Public Utility Holding Company Act. ${ }^{74}$ The SEC has stated what "indirect ownership," as used in these statutes, means in several typical situations. ${ }^{75}$ The holder of stock in a holding company is not to be regarded as the owner of securities owned by the holding company unless the stockholders are using the holding company as a personal trading or investment medium and it has no other substantial business. A partner is to be regarded as the owner of securities owned by a partnership to the extent of his pro rata interest in the partnership. In the case of an irrevocable trust, a trustee who can never become entitled to the corpus of the trust, and a beneficiary who is not the settlor and who exercises no control over the administration of the trust, is not to be regarded as the owner of securities held by the trust. Of course these interpretations may not prevail under $\$ \$ 3813$ and $162(\mathrm{~g})(2)$, but they give some tentative indication of the limits of "indirect ownership."

Regardless of how broadly the Commissioner and the courts construe the phrase "ownership, directly or indirectly," however, the $50 \%$ test is pitifully weak. What is important is not whether a creator of or substantial contributor to a charitable trust "controls"-through 50\% stock ownership or otherwise-a corporation with which the trust enters into a prohibited transaction. The crucial factor is whether the creator or contributor is in a position to derive any economic gain from such a transaction. This gain may accrue even though he in no way controls the corporation which the transaction benefits. For example, Royal Little, the president of Textron and the creator of the Rhode Island Charities Trust and MIT Trust, testified before the Ways and Means Committee that he did not control Textron, and that his entire family holdings, direct and indirect, amounted to less than $4 \%$ of Textron's total outstanding stock of $1,132,000$ shares. ${ }^{76}$ Yet

71. It also appears in $i d . \$ 45$.

72. See $i d$. $\$ \$ 24(\mathrm{~b})(2)$ and $503(\mathrm{a})$.

73. 4S Stat. 896 (1934), 15 U.S.C. \$ 78 p (a) (1946).

74. 49 Stat. 830 (1935), 15 U.S.C. $\$ 79 q$ (a) (1946).

75. Exchange Act Rel. 1965 (1938), 11 FED. REG. 10970 (1946).

76. House Hearings 553. The activities of Textron may have been instrumental in bringing about the enactment of the prohibited transactions provisions. See, e.g., the statement of Representative Forand of Rhode Island, $i d$. at 505 (". . . Mr. Little is one of those men who has been accused, either rightly or wrongly, of having used' trust funds for the operation of his business, and his has been one of the outstanding cases in the country over a number of years."); statement of the Cannon Foundation, Inc., 
if one of the trusts created by Little should in the future engage in a prohibited transaction with Textron, Little might benefit in no small way himself if Textron made a real killing. Instead of its $50 \%$ test, Congress should have included in the list of prescribed persons any corporation in which a creator of or substantial contributor to a charitable trust has any financial interest.

Furthermore, even accepting the $50 \%$ requirement, all the creator of a trust who owns $50 \%$ or more of the stock of a corporation need do to escape that requirement is to transfer part of his stock. He can transfer it to the trust itself, provided the settlor of a trust is not to be regarded as the "indirect owner" of stock held by the trust. For example, if Royal Little owned as much as $65 \%$ of the stock of Textron, he could simply transfer to the charitable trusts which he has created $16 \%$ of Textron's stock. Little would still exercise effective control over Textron through $49 \%$ stock ownership, and the trusts could enter into dealings with Textron without fear of engaging in a prohibited transaction under 3813.

To a limited extent the prohibited transactions set forth in $\$ \$ 3813$ and $162(\mathrm{~g})(2)$ overlap the Clifford regulations. Section 29.22(a)-21(e)(1), for example, provides that trust income is taxable to the grantor where a power exercisable by the grantor or any person not having a substantial adverse interest "enables the grantor or any person to purchase, exchange or otherwise deal with or dispose of" the income or corpus for less than an adequate consideration. ${ }^{77}$ Section 3813 , by contrast, applies only if the purchase or sale is made with a creator, a substantial contributor, a member of their families, or corporations $50 \%$ or more of whose stock they own. Other Clifford regulations, however, are more limited than $3813 .^{78}$ And they are concerned mainly with whether the power exists to enter into certain transactions, not with whether a prohibited transaction has actually been entered into. $^{79}$

Senate Hearings 496 ("We believe that title III has been presented by the Treasury Department because of certain abuses or alleged abuses which have come to the Treasury Department's attention. . . . We assume that the Treasury Department had in mind the conduct of a certain group of New England textile trusts.").

The Textron set-up is used as an example here simply because it has received such wide publicity and seems to have contributed to pressure for legislative action. Use of it as an example is not meant in any way to imply that either Textron or any of the trusts created by Royal Little has in the past or may in the future engage in any transaction which would fall under the "prohibited" definition.

77. Italics added.

78. E.g., U.S. Treas. Reg. 111, $\$ 29.22(\mathrm{a})-21$ (e) (2) (1945).

79. An exception in U.S. Treas. Reg. 111, $\$ 29.22(a)-21$ (e) (3) (1945), which provides that trust income is taxable to the grantor where he has borrowed the corpus or income and has not completely repaid the loan before the beginning of the taxable year. 


\section{Sanctions}

The basic sanction for engaging in a prohibited transaction is loss of exemption under 101(6) or loss of the unlimited charitable deduction under 162(a). One possible loophole arises: a trust whose deduction is limited under 162 (a) might seek a deduction under $162(\mathrm{~b})$ or (c) for income which it has paid or credited to charitable beneficiaries. ${ }^{80}$ This effort would be more likely to succeed if the payment to the charitable beneficiaries were outside the scope of 162(a). But since the Supreme Court's decision in Old Colony Trust Co. v. Commissioner, ${ }^{81}$ it seems to be well-nigh impossible to create a trust some of whose income may be paid to charitable beneficiaries and not have those payments come within 162(a)'s terms. In the Old Colony case the trust deed, after granting specified annuities, provided that whenever the annual net income of the trust equalled twice the amount of the annuities, the trustees could pay to exempt organizations of their choice "such sums as in their judgment may be paid without jeopardizing the annuities." On the death of the annuitants, the trustees were to distribute the corpus among such exempt organizations as they should choose. During the taxable year the trustee had paid $\$ 190,000$ of trust income to charities. The Court held that these payments were deductible under $162(a)$ as payments made "pursuant to the terms of the will or deed creating the trust," even though the charitable beneficiaries were not named in the instrument and even though it was uncertain in advance how much, if anything, would be paid to them each year. Of course in the Old Colony case the taxpayer was seeking to bring the payments within 162(a). But when the taxpayer is trying to take payments outside the scope of that subsection, the Commissioner will no doubt argue that any income which could be deducted under 162(a) must be deducted thereunder or not at all. Courts will likely agree with him, because to hold otherwise would permit taxpayers to by-pass completely the condition which Congress has now placed on the unlimited charitable deduction of 162(a)-namely, that a trust must not engage in a prohibited transaction.

Ordinarily an organization which engages in a prohibited transaction is to lose its exemption under 101(6) or its unlimited charitable deduction under 162 (a) only for taxable years subsequent to the taxable year in which the Secretary notifies the organization that it has engaged in the transaction. ${ }^{82}$ But if two conditions are met-namely, that the organization entered into the transaction with the purpose of diverting corpus or income from its exempt

S0. INT. KEv. ConE $\$ 162(b)$ permits estates and trusts a deduction for income which "is to be distributed currently ... to the legatees, heirs, or beneficiaries." Id. $\$ 162$ (c) permits, in the case of income which, "in the discretion of the fiduciary, may be either distributed to the beneficiary or accumulated," a deduction for income which "is properly paid or credited ... to any legatee, heir, or beneficiary."

\$1. 301 U. S. 379 (1937).

82. INT. REv. CoDE $\$ \$ 3813$ (c) (2), 162 (g) (2) (C). 
purposes, and the transaction involved a substantial part of the organization's corpus or income-then exemption may be denied retroactively with respect to any taxable year beginning after December 31, 1950.83

In any taxable year following that in which notice of denial of exemption was received, an organization may file a claim for exemption. If the Secretary is satisfied that the organization will not knowingly again engage in a prohibited transaction, it is to be exempt with respect to taxable years subsequent to that in which claim is filed. ${ }^{84}$ Thus an organization denied exemption for engaging in a prohibited transaction must lose its exemption for at least one taxable year.

In addition to denying exemption under 101(6) and limiting the deduction under 162(a), \$\$3813 and $162(\mathrm{~g})(2)$ provide other potent sanctions : disallowance to donors of income, estate, and gift tax deductions for gifts made to organizations whose exemption has been denied or whose charitable deduction has been limited..$^{85}$ Ordinarily a gift will be disallowed only if made to an organization whose exemption has already been denied (or whose 162(a) deduction has already been limited) because it engaged in a prohibited transaction in a prior taxable year. However, if certain requirements are met, a gift may be disallowed even though made in a taxable year which is the same,

83. Id. $\$ 3813$ (c) (2). In like manner the unlimited charitable deduction of a 162 trust may be denied retroactively. Id. $\S 162(\mathrm{~g})(2)(\mathrm{C})$. But again $\$ 162$ uses the term "such corpus or income." As to the difficulty of identifying "such corpus or income," see pages 866-67, stipra.

The Senate Finance Committee gave the following example of retroactive denial of exemption under 101(6): "A creates a foundation in 1955 ostensibly for educational purposes. B, as trustee, accumulates the income until 1960 when he uses this accumulated income to send $A^{\prime}$ s children to college, the real purpose of the foundation from its inception. Such foundation may lose its exemption for all years since its inception, that is, for taxable years 1955 through 1960 and future taxable years." SENATE REPORT 124. See also id. at $37,121$.

S4. INT. REv. CODE $\$ 3813(\mathrm{~d})$. Id. $\$ 162(\mathrm{~g})(2)(\mathrm{D})$ contains a similar provision for trusts whose deduction has been limited under $162(\mathrm{a})$.

S5. Id. $\$ \$ 3813(\mathrm{e}), 162(\mathrm{~g})(2)(\mathrm{E})$. Deductions are to be disallowed under $i d$. $\$ \$ 23(0)(2), 23(q)(2), 162(a), 505$ (a) (2), $812(d), 861$ (a) (3), 1004(a) (2) (B), and 1004 (b) (2) or (3). There are minor differences in the wording of these various charitable contribution sections. For example, the basic estate tax provision regarding charitable contributions, $\$ \$ 12$ (d), permits a deduction for gifts made either to an exempt corporation or to trustees "to be used . . exclusively" for an exempt purpose. Thus a gift made to a trust which is in part charitable and in part non-charitable is deductible, provided the gift itself is to be used exclusively for exempt purposes. Under the gift tax, on the other hand, a gift is deductible only if made to an organization "organized and operated exclusively" for an exempt purpose. Id. $\$ 1004$ (a)(2)(B). A discrepancy between $\$ \$ 23(\mathrm{o})$ and $162(\mathrm{a})$ has already been noted; see note 45 supra. See, generally, Lynch, The "Charities" Provisions of the Internal Reveme Code, 10 Ford. L. REv. 234 (1941). H.R. 6712, 80th Cong., 2d Sess. (1948), would have made uniform most of the charitable contribution provisions of the income, estate, and gift tax. The bill passed the House, but was never reported out of the Senate Finance Committee.

On $\$ 812(\mathrm{~d})$, see Ross, $A$ Primer on Charitable Fonndations and the Estate Tax, 27 TAXES 116 (1949). 
or prior to, the taxable year in which the prohibited transaction occurs. These requirements are that the organization's exemption be denied (or that its 162 (a) deduction be limited) retroactively, and that the donor or a member of his family be a party to the prohibited transaction. ${ }^{\text {s6 }}$

There is no provision that the latter requirement can be satisfied merely by the donor's business being a party to the prohibited transaction. Suppose a prohibited transaction is entered into between a trust which the donor created and a corporation which he controls, but the donor is careful not to participate personally in the negotiations. If the Commissioner denies retroactively the trust's exemption under $101(6)$ and then seeks to disallow retroactively the donor's deduction under the income, estate, or gift tax, the donor will argue that he was not a party to the prohibited transaction. If the donor controls the corporation through $50 \%$ stock ownership, then the Commissioner might find that he was a party to the transaction on the ground that the corporation was a party. But if the donor controls the corporation through less than $50 \%$ stock ownership, will the Commissioner feel himself bound by the 50\% test laid down in another part of 3813 and hold that the donor was not a party?

\section{Gifts of Stock}

The Senate rejected entirely a provision in the House bill barring deductions under the income, estate, or gift tax for gifts of stock to an exempt organization created by a donor to continue control of an existing business. ${ }^{87}$ The deduction was to be disallowed whenever the donor gave stock in a corporation to an exempt organization which he controlled, ${ }^{88}$ and the donor together with members of his family owned at least $50 \%$ of the voting stock or $50 \%$ of the value of all stock of the corporation. For this purpose stock already owned by the controlled trust was to be regarded as owned by the donor. The Senate Finance Committee eliminated the measure because it felt that if these deductions were not allowed, "still larger funds would be lost to private charity." 80

\section{IMPROPER ACCUMULATIONS}

Section 3814 provides for loss of exemption of certain 101(6) organizations if their accumulated income: (1) is unreasonable in amount or duration in order to carry out their exempt purpose; (2) is used to a substantial degree for

S6. INT. REv. CODE $\$ \$ 3813(\mathrm{e}), 162(\mathrm{~g})(2)(\mathrm{E})$.

87. House Bill $\$ 331(a)$, supra note 64 , at 32 .

88. The donor was to be regarded as "controlling" the exempt organization whenever he, together with members of his family, (a) comprised a majority of the officers, directors, or trustees of the organization; (b) had the power to fill vacancies in the case of a majority of the officers, directors, or trustees; or (c) had any power with respect to the voting or disposition of the donated stock. Ibid.

89. SENATE REPORT 39. 
other than their exempt purpose; or (3) is invested in such a manner as to jeopardize the carrying out of their exempt purpose. ${ }^{20}$ This section applies to the same $101(6)$ organizations as $\$ 3813$, mainly private charitable trusts. ${ }^{01}$ If a 162 trust improperly accumulates income, the amount otherwise allowable as a deduction under 162(a) is limited to the amount actually paid out during the taxable year and in no event is to exceed 15\% of the net income of the trust. ${ }^{92}$

Sections 3814 and $162(\mathrm{~g})(4)$ represent a compromise between the House and the Senate. The House felt that tax exemption of private charitable trusts should be restricted in the main to income actually distributed to charity. ${ }^{93}$ The House bill would have permitted a charitable trust to accumulate tax-free an amount equal to the highest annual gross income realized during the taxable year or during the preceding five taxable years. It would not have taxed any trust created under an instrument requiring that all corpus and income be used for an exempt purpose within five years after the trust's creation. It would have permitted the tax-free accumulation for a period of twenty-five years of income from property set aside for a charitable purpose under the will of a decedent. Finally, it would have excepted all income from property transferred in trust prior to June 1, 1950, under an instrument forbidding the current distribution of earnings. But with these exceptions, a private charitable trust was to be taxed on all income not paid to beneficiaries within $2 \mathrm{I} / 2$ months after the close of the taxable year. ${ }^{94}$ In the case of a 162 trust, no amount otherwise allowable under 162 (a) as a deduction was to be allowed with respect to income which was accumulated.95 Exceptions were provided similar to those provided for $101(6)$ trusts.

The Senate felt that the House provision, despite its exceptions, was "too inflexible" and "would seriously injure many worth-while educational and charitable projects." tions and substituted a new $\$ 153$, requiring certain 101(6) organizations and ail trusts claiming a deduction under 162(a) to file with the Commissioner information regarding their income, expenses, disbursements, and accumulations. The Conference Committee, while retaining $\S 153$, reinstated a modified version of the House measure for taxing accumulated income. ${ }^{97} \mathrm{But}$ in doing so it removed all the sting from the House provisions, by inserting such phrases as "unreasonable in amount or duration" and "used to a substantial degree."

90. INT. REv. CoDE $\$ 162(\mathrm{~g})(4)$ contains a similar provision for $\$ 162$ trusts.

91. See note 61 supra.

92. INT. Rev. CoDE $\S 162(\mathrm{~g})(4)$.

93. See House RePort 40-1, 115-23.

94. House Bill $\$ 301$ (a), supra note 64 , at 27-9.

95. House bill $\$ 321$ (a), supra note 64 , at 30 .

96. SenAtE REPORT 34.

97. H.R. REP. No. 3124, 81st Cong., 2d Sess. 15 (1950). 


\section{INCREASEd PUblicity}

Congress apparently had three purposes in mind in enacting $\S 153$ : to help the Commissioner enforce the accumulated income provisions; $; 8$ to make information regarding charitable trusts available to the public; and to provide the basis for possible further legislation..$^{99}$

Actually $\S 153(\mathrm{a})$ adds very little to existing law. For the past seven years substantially the same information has been required under $\$ 54(\mathfrak{f})$, which applies to the same exempt organizations as $\S 153(\mathrm{a})$, mainly private charitable trusts. ${ }^{100}$ Form 990, the informational return issued under 54(f), has since 1944 called for every item of information required by the new section with the possible exception of item (6)-disbursements out of principal in the current and prior years. ${ }^{101}$

Section 153(b), on the other hand, requires a considerable amount of new information from all trusts claiming a charitable deduction under 162(a). In the past these trusts have filed an ordinary fiduciary return, which requires simply a listing of the charitable beneficiaries for whom amounts were paid or permanently set aside. Under the new section these trusts are required to list separately the amount of the charitable deduction actually paid out and that permanently set aside. They are also required to set forth the amount for which charitable deductions have been taken in prior years but which has not yet been paid out, the amount paid out of principal for charitable purposes, and a balance sheet. ${ }^{102}$

All the information required by $\S 153$ is to be made available to the public in such manner as the Secretary prescribes. ${ }^{103}$ In this important respect

98. That this was one of Congress' purposes is confirmed by the fact that it recently amended $\S 153$ (b) so as to exclude trusts all of whose net income, "determined under the applicable principles of the law of trusts, is required to be distributed currently to the beneficiaries." Pub. L. No. 35, 82d Cong., 1st Sess. (May 17, 1951). The committee reports on this amendment state: "Section 153(b) was enacted by the Congress as a part of its tax program to prevent the unreasonable accumulations of income of trusts claiming charitable deductions by providing the charitable beneficiary and the general public with information on the amount of income accumulated tax-free." H.R. REP. No. 284, 82d Cong., 1st Sess. (1951) ; SEN. Rep. No. 222, 82d Cong., 1st Sess. (1951).

99. The Senate Finance Committee felt that publicizing information about charitable trusts would encourage distributions. SENATE REPORT 35.

100. Thus the same discrepancies exist between $\$ \$ 153$ (a) and 3813 as between $\$ \$ 54(f)$ and 3813. See note 61; supra.

101. The Commissioner has recently issued a new form, 990-A, to be used by all $101(6)$ organizations [except those exempt from filing returns under 54(f)] for accounting periods beginning after December 31, 1949. See U.S. Treas. Reg. 111, \$29.153-1 (1951).

102. All trusts claiming a charitable deduction under 162(a) for taxable years beginning after December 31,1949, must file, in addition to the regular fiduciary return (Form 1041), a new informational return (Form 1041-A). See id. \$29.153-2 (1951).

103. INT. REv. CoDE $\$ 153$ (c). Most of the information furnished on the new Form 990-A and all of the information furnished on the new Form 1041-A "shall be a matter of public record, and shall be open to public inspection, during regular hours of business, in 
153 differs from 54(f), which made no provision for publicizing the returns filed under it.

To help him enforce the prohibited transactions provisions, the Commissioner has included on the new form issued under $\S 153$ (a) a series of questions regarding activities which might be classified as "prohibited." Every 101(6) organization required to file an informational return must state whether, during the taxable year, any prescribed person ${ }^{104}$ (1) borrowed any part of its income or corpus, (2) received from it any compensation for personal services, (3) had any part of its services made available to him, (4) purchased or sold any securities or other property from or to it, or (5) diverted any part of its income or corpus by any transaction. If the answer to any question is "yes", the organization must attach a detailed statement. ${ }^{105}$ For no apparent reason, however, the Commissioner has not as yet required trusts claiming charitable deductions under 162 (a) to answer a similar set of questions.

\section{CoNCLUSION}

Title III of the Revenue Act of 1950 is a fairly inept piece of legislation. Congress was lenient when it should have been harsh and harsh when it should have been lenient.

Taxing unrelated business income and denying exemption to feeder organizations. The tax on unrelated business income and the denial of exemption to feeders are not likely to be substantial revenue raisers. ${ }^{106}$ Congress properly regarded the main purpose of these measures as the avoidance of unfair competition between taxable and tax-exempt businesses. ${ }^{107}$

It is often asserted that an exempt business has a twofold advantage over a taxable business: it can cut prices, and it can accumulate a larger surplus with which to expand. ${ }^{108}$ The second of these assertions probably has more truth in it than the first. ${ }^{100}$ This is not because a businessman never takes

the office of the collector for the district in which the forms are filed." U.S. Treas. Reg. $111, \$ 29.153-3$ (1951).

104. See pages $867-69$ supra.

105. Int. Rev. Bureau, Form 990-A, supra note 101.

106. See note 9 supra.

107. See House RePort 36 ("The problem at which the tax on unrelated business income is directed here is primarily that of unfair competition."); SENATE REPORT 28 (same).

108. See Finkelstein, Freedom from Uncertainty in Income Tax Exemptions, 48 Mich. L. Rev. 449, 460 (1950); Latcham, Private Charitable Foundations: Some Tax and Policy Implications, 98 U. of PA. L. Rev. 617, 647 (1950); Hearings, stura note 5, at 3534-5 (remarks of Chairman Knutson).

109. See the statement of John Gerdes in the 1947 hearings: "The only advantage you really get from tax exemption is the ability to accumulate and keep in the business money which would otherwise have to be paid out in the form of income taxes." Hearings, supra note 5 , at 3534 . 
taxes into account in determining his price policy. Although the income tax is not an element in the cost of production and should have no effect on the "optimum price" for a corporation to charge, businessmen do not always follow the dictates of economic theory. But even so, the price-cutting advantages of an exempt over a taxable business are dubious. Suppose two corporations are identical in all respects except that $A$ is tax-exempt and $\mathrm{B}$ is not. Assuming the corporate tax rate to be $50 \%$, if $\mathrm{A}$ is making $10 \phi$ on the dollar, then $\mathrm{B}$ is making $5 \%$. If $\mathrm{A}$ cuts its price so that it makes only $5 \dot{\phi}, \mathrm{B}$ will cut its price until it is making only $2 \mathrm{I} / 2 \dot{\phi}$. This price cut has resulted in a greater absolute loss to $A$ than to B. If A further cuts its prices until it makes only $1 \xi$, B will cut its prices until it is making $1 / 2 \phi$. It is apparent that A's absolute advantage over $B$ declines proportionately as prices are cut lower and lower. Of course it may be possible for $A$ to maintain its price-cutting policy until $B$ goes out of business, and then raise prices again. But it will be a severe drain on A's financial resources so long as the price war continues. And it seems unlikely that exempt institutions like universities and hospitals, which are clamoring for funds, will forego current income on the risk that they can drive out a competitor after a lengthy price war. No evidence was adduced before Congress to show price cutting on the part of businesses owned by exempt institutions.

A tax-exempt business can, however, accumulate a larger surplus than a taxable business, which may help it to weather lean years or to expand. But it is not necessary to tax the former in order to eliminate this possible competitive advantage. One solution might be to require that an exempt business distribute each year to its beneficiaries an amount equal to what it would otherwise have to pay in federal income taxes. ${ }^{110}$ But this would not really equalize the situation, because the exempt business could retain the remainder of its earnings for expansion purposes, whereas the taxable business might be forced to distribute as dividends part of its income after taxes. A preferable approach would be to set a flat figure, such as $75 \%$, and require that every exempt business distribute at least that portion of its income to its beneficiaries each year. ${ }^{111}$ A scheme of this sort would go far towards eliminating any possible competitive advantage of exempt over taxable businesses. Yet it would not reduce the source of funds for universities, hospitals, and other exempt institutions, which are already in dire financial straits. ${ }^{112}$

110. For proposals to this effect, see Finkelstein, supra note 108 , at 460 ; Jenks, The Use and Misuse of Section 101(6), New York UnIversity Seventr ANNuAL Institute on Federal Taxatton 1051, 1062 (1949); Hearings, supra note 5, at 3527 (testimony of John Gerdes).

111. H.R. 2976, 81st Cong., 1st Sess. (1949) would have required all 101(6) organizations to distribute annually $75 \%$ of their net income, exclusive of capital gains added to principal, unless a plan to accumulate more than $25 \%$ was approved by the Commissioner.

112. Leading educators who appeared before the House and Senate committees were strongly opposed to taxing income derived from the direct ownership of commercial 
Prohibited transactions and improper accumulations. In those parts of the new Act dealing with prohibited transactions and improper accumulations, on the other hand, Congress stopped far short of what it should have done. Not even the House was willing to go as far as its bête noir, Royal Little, who would have prohibited any transaction-including any purchase, sale, exchange, loan, or lease, or the receipt of any compensation-between a private charitable trust and the persons enumerated in $\$ 3813.113$ Then the Senate further weakened the House version by introducing a number of qualifying phrases which should prove ripe subjects for litigation. Both houses adopted a test of $50 \%$ stock ownership which overlooks the facts of corporate life and makes circumvention of the prohibited transactions provisions extremely simple. Neither house considered a provision disqualifying a person from acting as trustee of an exempt trust if he controls a business

enterprises by exempt institutions. They regarded such a tax as socialism's opening wedge. See Senate Hearings 499, 507 (testimony of Harold Stassen, president, University of Pennsylvania) ("I consider that this is an outrageous proposal. . . I believe that the objective of the men in the Treasury who drew this bill without consultation with the American colleges and universities was to bring the American colleges and universities under the control of the Federal Government."); id. at 567 (testimony of Stuart Hedden, trustee, Wesleyan University) ("It provides an opening wedge toward the socialistic intervention of Government into our colleges. ..."); id. at 526 (testimony of Carter Davidson, president, Union College) ("[A]n attack by the Federal Government upon our long-established tax-exemption may mark the beginning of the end of privately supported education in America."); House Hearings 573 (testimony of Philip C. Pendleton, treasurer, University of Pennsylvania) ("We fear, once begun, taxation of some activities could eventually lead to the taxation of all."). These men felt that as a matter of educational policy, however, colleges should not engage directly in commercial activities unrelated to their exempt function. See Senate Hearings 527 (testimony of Carter Davidson) ("[T]here is virtually unanimous agreement among the colleges that educational institutions should not engage in commercial businesses not related to the purpose of education. . . .). This attitude is also reflected in Association of Asrerican Universtties, Report of the Committee on Financial Support and Taxation 3 (1950): "The Committee believes it is neither proper nor in the public interest for a university to carry on directly any manufacturing or mercantile business having no significant connection with the educational or scientific work of the university other than the attribute of producing income for it."

On the other hand, the educators who testified were very much in favor of taxing feeder corporations. See House Hearings 573 (testimony of Philip C. Pendleton) ("The separately organized corporation engaged in business activities unrelated to education should not be entitled to exemption from the corporate-income tax, even when the entire profit of such a corporation goes to a tax-exempt educational institution.") ; Senate Hearings 374-5 (testimony of J. $\mathrm{R}$. Killian, Jr., on behalf of Committee on Financial Support and Taxation of the Association of American Universities) ("Our committee believes that when a manufacturing or mercantile business is carried on as an entity separate from the university and has no substantial connection with educational or scentific work of the university, it should be taxed."). Mr. Stassen not only suggested that feeder corporations be taxed; he also suggested, as a part of the "moral code of the universities," that a university should never operate a commercial enterprise through a feeder or otherwise. Id. at 501-2.

113. House Hearings 531, 535-6. 
in which the trust has invested a substantial portion of its assets. ${ }^{114}$ The House provision denying income, estate, and gift tax deductions for gifts of stock in a controlled corporation was rejected in its entirety. Finally, the House measure taking accumulated income was replaced by a vague provision which gives no clear direction to the taxpayer or the Commissioner.

114. See, e.g., the milder of two proposals set forth in Comment, The Modern Philanthropic Foundation: A Critique and a Proposal, 59 Y $\mathrm{ALE}$ L.J. 477, 506 (1950). 